\title{
Victim-Offender Mediation: The Road to Repairing Hate Crime Injustice
}

\author{
ALYSSA H. SHENK*
}

\section{INTRODUCTION}

For centuries, the adage "Crime Wounds . . . Justice Heals,"1 has been at the heart of the American criminal justice system. Traditionally, the focus has been on crime as a violation of the law, offering punishment as the appropriate remedy. ${ }^{2}$ By limiting reparation to the punishment of the offender, this system has neglected to take into account the needs of the victim, ignoring one of the most important aspects of the justice system. ${ }^{3}$

The American criminal justice system has been appropriately described as being retributive, measuring justice by the amount of punishment inflicted upon the offender. ${ }^{4}$ Punishment, although conceivably just, cannot achieve results that will aid in repairing the actual harm done to the victim. ${ }^{5}$ Inflicting punishment cannot restore the victims" losses, "answer their questions, relieve their fears, help them make sense of their tragedy or heal their

* B.A., University of Wisconsin-Madison, 1998; J.D. Candidate, The Ohio State University Moritz College of Law, 2002. I would like to dedicate this Note to my Grandfather Sol A. Shenk as I have followed in his footsteps as the third generation to attend The Ohio State University Moritz College of Law. A special thank you to my Aunt Janice and Uncle Jack for their assistance in writing this Note. I would also like to thank my parents and my sister for their ongoing support throughout my academic career.

${ }^{1}$ Harry Mika \& Howard Zehr, Restorative Justice Signposts, at http://ssw.che.umn.edu/rjp/resources/documents/cumb99c.pdf (last visited Oct. 8, 2001).

2 Catherine Edwards, Paying for What They've Wrought, INSIGHT ON THE NEWS, July 26, 1999, at 46.

3 Marty Price, Crime and Punishment: Can Mediation Produce Restorative Justice for Victims and Offenders?, at http://www.vorp.com/articles/crime.html (last visited Oct. 8,2001 ) [hereinafter Crime and Punishment].

4 See Ctr. For Restorative Justice \& PEACEMAKING, Restorative Justice for VICTIMS, COMMUNITIES AND OFFENDERS 2 (1996), available at http://ssw.che.umn.edu/rj $\mathrm{p} /$ resources/documents/cctr96a.pdf (last visited Oct. 12, 2001) [hereinafter RJ FOR VICTIMS]. Retributive justice focuses "on public vengeance, deterrence, and punishment through an adversarial process." OFFICE OF JUVENILE JUSTICE \& DELNQUENCY PREVENTION, U.S. DEP'T OF Justice, BALANCED AND ReStorative Justice PROGRAM SUMMARY 6 (1994).

5 "Traditional 'punishment' alone has been seen to encourage those that break the law to focus on themselves as 'victims of the system' rather than focusing on the harm they caused their victims and the community." RJ FOR VICTIMS, supra note 4, at 5 (quoting MARTIN WRIGHT, JUSTICE FOR VICTIMS AND OFFENDERS 11 (1991)). 
wounds." In the traditional criminal justice system, the victim is rarely given the opportunity to explain what his or her needs are, let alone provide any thoughts on how the case should be resolved. ${ }^{7}$ This system has done an excellent job of "keep[ing] crime victims, the community, and offenders from deciding how society will respond to crime."8

Over the years, there has been a developing trend in the criminal justice system to put the needs of the victims before the interests of the system. ${ }^{9}$ The changing mentality of the criminal justice system is symbolic of a move toward restorative justice where the focus is primarily on the needs of victims. This shift in focus includes permitting victims to participate actively in the criminal justice process by giving them a decision-making role while supporting their participation in the process. ${ }^{10}$ Restorative justice not only seeks to engage victims in the justice process, but it also turns to the community as well as the offender in order to examine the ways in which an offender may directly repair the harm done to the victim and society. ${ }^{11}$ Restorative justice suggests that the criminal justice system can repair the harm done to both victims and the community by utilizing such methods as "negotiation, mediation, victim empowerment, and reparation."12

Restorative justice may be applied in many different settings, taking a variety of forms. However, victim-offender mediation has emerged as the most well-known and effective means of employing the theory of restorative justice. ${ }^{13}$ Victim-offender mediation emerged in the United States in the late

${ }^{6}$ Crime and Punishment, supra note 3.

${ }^{7}$ RJ FOR VICTIMS, supra note 4, at 9.

8 Id.

${ }^{9}$ See id. This growing trend has become known as the restorative justice movement, a social movement advocating justice reform. Marty Price, Personalizing Crime, DISP. RES. MAG., Fall 2000 at 8, 9. Restorative justice has been implemented "at state, regional and/or local levels" in almost every state. Id. Among those "states that have officially adopted restorative justice principles and policies" many "require any justice program that receives state funding to adhere to these principles." $I d$.

${ }^{10}$ RJ FOR VICTIMS, supra note 4 , at 9.

${ }^{11} \mathrm{Id}$. Restorative justice seeks to broaden relationships between victims, offenders, and community members. OFFICE OF JUVENILE JUSTICE \& DELINQUENCY PREVENTION, supra note 4, at 6 (citing Richard Lawrence, Reexamining Community Corrections Models, 37 CRIME \& DelinQ. 449 (1991); Howard Zehr, Changing LeNSES: A NeW FOCUS FOR CRIME AND JUSTICE (1990)).

12 OfFice of Juvenile Justice \& DelinQuenCy PREVENTION, supra note 4, at 6. This Note specifically addresses restorative justice in terms of victim-offender mediation.

${ }^{13}$ Mark S. Umbreit, What is Restorative Justice, at http://ssw.che.umn.edu/rjp/resou rces/documents/cumb99c.pdf (Apr. 15, 1999). In the last fifteen years, the number of criminal conflicts which are sent to mediation has grown tremendously. Mark William 
1970 s, ${ }^{14}$ and its use continues to flourish. ${ }^{15}$ Originally employed in cases involving property crimes or minor assaults, victim-offender mediation programs have become increasingly widespread. ${ }^{16}$ In recent years the scope of victim-offender mediation programs has deepened, expanding the process to provide for the mediation of severely violent crimes. ${ }^{17}$

This Note proposes broadening the scope of victim-offender mediation to include incidents of hate crimes. For centuries hate crimes have been part of life in American society. However, in recent years these crimes have been on the rise with increasing severity. ${ }^{18}$ This increase in hate crimes has prompted both federal and state governments to take action. ${ }^{19}$ Most efforts to deter hate crimes have been in the form of hate crimes legislation, even though other methods of prevention are being utilized. ${ }^{20}$ Although vital to combating incidents of hate crimes, hate crimes legislation without adequate support

Bakker, Comment, Repairing the Breach and Reconciling the Discordant: Mediation in the Criminal Justice System, 72 N.C. L. REV. 1479, 1480 (1994).

${ }^{14}$ Mark S. Umbreit \& Robert B. Coates, Victim-Offender Mediation: A Review of Research in the United States, in MAKING AMENDS 190, 191 (Gwynn Davis ed., 1992).

15 CTR. FOR RESTORATIVE JUSTICE \& PEACEMAKING, NAT'L SURVEY OF ViCTIM OFFENDER MEDIATION PROGRAMS IN THE U.S. 3 (2000) [hereinafter NAT'L SURVEY OF VOM]. "In the late 1970s, only a handful of VOM and reconciliation programs existed;" however, today, there are more than 1000 programs in existence throughout North America and Europe. Id.

16 Id; see also Glenda L. Cottam, Mediation and Young People: A Look at How Far We've Come, 29 CREIGHTON L. REV. 1517, 1536 (1996).

17 Crime and Punishment, supra note 3.

18 STEPhen Wessler, Center for THE STUdy and Prevention of Hate VIOLENCE, AdDRESSING HATE CRIMES: SiX INITIATIVES THAT ARE ENHANCING THE EFFORTS OF CRIMINAL JUSTICE PRACTITIONERS 1 (2000). In recent "years the nation has experienced an alarming number of disturbing and sometimes deadly hate crimes." Id. It has been these crimes that "have left a trail of dead or wounded victims and traumatized, fearful communities." Id; see also infra Part V.

19 Nat'l CRiminal Justice Ass'N, A POlicymakeR's Guide to Hate CRimes 1 (1997) [hereinafter NCJA] (citing JACK LEVIN \& JACK MCDEVITT, HATE CRIMES: THE Rising TIDE OF BIGOTRY AND BLOODSHED 1-8, 75, 86-87 (1993)).

20 Other responses to hate crime throughout the nation have included the establishment of "innovative preventive programs in schools" as well as the utilization of additional resources in the training of both police officers and prosecutors. WESSLER, supra note 18 , at 1 . Many states are also beginning to turn to specialized training for law enforcement officers as a means of preventing further incidents of hate crimes. LU-IN WANG, HATE CRIMES LAW $\S 9.03$ (2000). For example, "California has enacted a special sentencing provision that requires hate crime offenders who are granted probation to complete, as a condition of probation, a 'class or program on racial or ethnic sensitivity, or other similar training in the area of civil rights,' if such a course is available." Id. at $\S 9.04$ (quoting CaL. PENAL CODE $\S 422.95(a)(1)$ (West 1999)). 
does not provide appropriate justice and is not alone sufficient to deter the future commission of hate crimes. Therefore, this Note proposes the adoption of a paradigm which integrates both hate crimes legislation and a victimoffender mediation process.

This Note explores the themes of restorative justice and how they impact the resolution of hate crimes in the contemporary American criminal justice system. Part II discusses the restorative justice movement and how it is symbolic of the changing mentality of the criminal justice system. Part III examines the victim-offender mediation process and why it has become the most widely employed form of restorative justice. In addition, this section explores the scope of victim-offender mediation programs and the recent expansion of the process to include crimes of severe violence. Part IV provides an overview of the status of hate crimes in the United States. Part V examines the most prevalent hate crimes being committed in the United States today, recognizing the increased caliber of severity of many of these offenses. Part VI discusses the development of hate crimes legislation in an effort to prevent the further commission of hate crimes. Moreover, this section proposes that an integrated paradigm of hate crimes legislation and victim-offender mediation is necessary to most appropriately address the issue of hate crimes and deter such incidents in the future. Part VII concludes, briefly discussing the movement toward restorative justice and, in particular, the concept of victim-offender mediation and its implications for both hate crimes prevention and the American criminal justice system as a whole.

\section{THE RESTORATIVE JUSTICE MOVEMENT}

\section{A. The Inadequacies of The Traditional Criminal Justice System}

The nature of crime runs deeper than the mere act of breaking the law. ${ }^{21}$ Crime is the manifestation of something greater, signifying the destruction of the social fabric of a community, a process by which humans violate both the personal and social relationships of other humans. ${ }^{22}$ In simple terms, "[c]rime is the violation of one human being by another." 23 The role of

21 Mark S. UMBreit \& JEAN GREENWOOd, CTR. FOR RESTORATIVE JUSTICE \& PEACEMAKING, MULTICULTURAL IMPLICATIONS OF RESTORATIVE JUSTICE: POTENTIAL PITFALLS AND DANGERS 3 (2000) [hereinafter MULTICULTURAL IMPLICATIONS OF RJ].

22 Id.

23 Id. 
justice is designed to repair the harm done by crime and to rebuild the relationships that were destroyed. ${ }^{24}$

The current criminal justice system and the traditional means of ensuring justice make it difficult for the victim and community to achieve the kind of justice necessary to repair and rebuild. ${ }^{25}$ Traditionally, punishment has been utilized as a means of conveying that justice has been done; however, "[p]unishment alone is unlikely to convince the offender to become a contributing member of the community." 26 In addition, punishment is merely a passive act ${ }^{27}$ that does nothing to encourage offenders to be accountable for their actions. ${ }^{28}$ Therefore, it is important to provide offenders with a chance "to become meaningfully accountable to their victims, and to become responsible for repairing the harm they have caused." 29

\section{B. Benefits of Restorative Justice Over Traditional Format}

The theory of restorative justice has created an outlet to the traditional notions of the criminal justice system by suggesting "a new way of thinking about crime, community, and working together for the future." 30 With this notion of restorative justice comes a vision in which victims play a central

\section{${ }^{24} I d$.}

${ }^{25}$ Advocates of restorative justice believe that the traditional notion of retributive justice, which focuses on incarcerative practices as a means of achieving justice, only "add[s] more harm to the world." Bakker, supra note 13, at 1514. They believe the answer lies in attempting to "balance the criminal harm already done with support for the victim and a requirement that the offender make reparations." Id. (citing Martin Wright, Victim-Offender Mediation as a Step Towards a Restorative System of Justice, in Restorative Justice on TRial: Pitfalls and Potentials of Victim-OfFender MEDIATION-INTERNATIONAL RESEARCH PERSPECTIVES 525, 525-26 (Heinz Messmer \& Han-Uwe Otto eds., 1992)).

${ }^{26}$ Marty Price, Can Mediation Produce Justice?, ADR REPORT, Oct. 29, 1997, at 6,

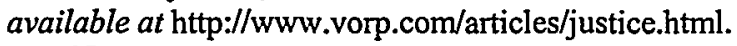

27 Id.

${ }^{28}$ Bakker, supra note 13 , at 1517 . It is of far greater importance to restore any emotional or material losses that occur as a result of the crime than to impose costly punishment on the offender. MARK S. UMBREIT \& JEAN GREENWOOD, CTR. FOR RESTORATIVE JUSTICE \& PEACEMAKING, GUIDELINES FOR VICTIM-SENSITIVE VICTIMOFFENDER MEDIATION: RESTORATIVE JUSTICE THROUGH DIALOGUE 1 (2000) [hereinafter GUIDELINES].

${ }^{29}$ Price, supra note 26 , at 6.

${ }^{30}$ RJ FOR VICTIMS, supra note 4, at 6 . The restorative justice movement seeks "to redefine crime as an offense against an individual, providing a forum for the victim to participate in the resolution and restitution of that crime." Richard Delgado, Prosecuting Violence: A Colloquy on Race, Community, and Justice, 52 STAN. L. REV. 751, 756 (2000) (citations omitted). 
role in the way crimes are resolved and the type of reparation received for harm incurred. ${ }^{31}$

Restorative justice has surfaced as a theory directly focused on providing opportunities for those who have been most affected by crime. ${ }^{32}$ This "victim-centered response to crime" allows victims, offenders, families and community members "to be directly involved in responding to the harm" resulting from the crime. ${ }^{33}$ Restorative justice bestows upon the victim, the community, and the offender an obligation to right the harm that has been done and, in particular, creates a sense of accountability for the offender to accept responsibility and work to repair the harm. ${ }^{34}$

The goals of restorative justice are three-fold. First, restorative justice is predicated upon the idea of greater victim involvement. ${ }^{35}$ Victims have had little opportunity for their voices to be heard under the traditional criminal

31 RJ FOR VICTIMS, supra note 4, at 6. Most types of restorative justice programs tend to operate in the juvenile justice system although some of these programs have also proved "effective in the adult criminal justice system" as well. CTR. FOR RESTORATIVE JUSTICE \& PEACEMAKING, FACT SHEET: THE IMPACT OF RESTORATIVE JUSTICE (1997), at http://ssw.che.umn.edu/rjp/Resources/Documents/cumb97a.pdf [hereinafter CRJ FACT SHEET].

32 Umbreit, supra note 13. In his book, Howard Zehr defines restorative justice:

Instead of focusing solely on the offender and defining justice as the placing of blame (guilt) and the administration of pain (punishment), restorative justice recognizes that crime results in harm to the victim, the community and the offender. Restorative justice seeks to right the wrong through meaningful accountability by the offender, restoring the losses, as much as possible, to all who have suffered due to the crime. Restorative justice is not a program or set of programs, but a guiding philosophical paradigm.

Marty Price, Victim-Offender Mediation: The State of the Art, VOMA QUARTERLY (FallWinter 1996), at http://www.vorp.com/articles/art.html [hereinafter The State of the Art] (quoting Howard ZEHR, CHANGING LeNSES: A NEW Focus For CRIME AND JUSTICE (Herald Press 1995)).

33 Umbreit, supra note 13, at 1.

34 See RJ FOR VICTIMS supra note 4, at 16. Restorative Justice creates a process in which the victim, the offender, and the community all have an obligation to make things right by "search[ing] for solutions which promote repair, reconciliation, and reassurance." Bakker, supra note 13, at 1515 (quoting ZEHR, supra note 11, at 181). A restorative justice inquiry places emphasis on three specific questions. "First, what is the nature of the harm resulting from the crime? Second, what needs to be done to 'make it right' or repair the harm? Third, who is responsible for the repair?" Price, supra note 9, at 9. The answer to these questions lies at the heart of the restorative justice process and require consideration by the victim, the offender and the community.

35 See RJ FOR VICTIMS, supra note 4, at 4. 
justice system. ${ }^{36}$ In contrast, restorative justice provides victims with a chance for face-to-face interaction with the person responsible for the crime, so the victim can express directly to the offender the impact of the offense. ${ }^{37}$ By engaging in restorative justice programs, victims "regain their personal power by stating their own needs and how their needs can best be met." 38 Second, restorative justice is aimed at promoting a greater sense of community protection. ${ }^{39}$ By involving various community members, agencies, and organizations in an effort to "bridge gaps between people and organizations and strengthen community bonds," restorative justice aids communities in furthering their sense of safety and provides them with the ability to engage in active peacemaking. ${ }^{40}$ Third, restorative justice focuses on enhancing offender accountability. ${ }^{41}$ Restorative justice programs provide a forum in which offenders can learn about the harm that they have inflicted on the victim and ways in which they can make amends to both the victim and the community. 42

${ }^{36} I d$. at 1. Victims often favor longer prison terms for offenders because they are presented with no other options, and they are not asked what they really want. Gordon Bazemore, Will the Juvenile Court System Survive?: The Fork in the Road to Juvenile Court Reform, 564 ANNALs 81, 91 (1999). As a result, "[the system] gives them Door Number One or Two, when what they really want is behind Door Number 3 or 4. ." Id. (alteration in original).

\section{CRJ FACT SHEET, supra note 31.}

${ }^{38} \mathrm{RJ}$ FOR VICTIMS, supra note 4, at 1. In a 1994 study conducted by Dr. Mark Umbreit of four victim-offender mediation programs in the United States, it was found that those "[v]ictims who go through mediation were more likely to see their experience with the justice system as fair than those who went through the traditional court process." Id. at 4 . In addition, the study found that those who participated in mediation thought that the experience humanized the response to crime. Id. The study also noted that victimoffender mediation was responsible for a reduction in fear among victims. Id. Specifically, "[b]efore mediation, $25 \%$ of victims were afraid the offender would hurt them again." However, "[a]fter mediation, only $10 \%$ of victims thought the offender would revictimize them." Id.

${ }^{39} \mathrm{Id}$. at 4.

40 Id. at 1.

${ }^{41}$ Id. at 5 . The belief behind accountability is "that when an offender commits an offense, the offender owes a debt to the victim and the community." Id. at 16. Through restorative justice, an offender becomes accountable when given the opportunity to "honestly understand the impact of his or her behavior" and "take action to make things right and repair the harm." Id.

$42 \mathrm{Id}$. at 1 . Furthermore, "[r]estorative [j]ustice programs send a strong message to offenders that criminal behavior is not acceptable while allowing offenders ways to make amends to their victims, gain skills, and increase their positive attributes so they can come back into the community as productive members." Id. at 4 . One example of a restorative justice program which allows for offender accountability is family group 
Restorative justice provides something for everyone and instills a great sense of hope that things will get better for the victim, the community, and the offender. Restorative justice affords victims a chance to become a part of the process and to take an active role in achieving justice that will meet their individual needs. As for the offender, restorative justice provides skills and confidence while making real the impact of the crime, all of which aids in future deterrence. ${ }^{43}$

\section{VICTIM-OFFENDER MEDIATION: RESTORATIVE JUSTICE IN ACTION}

\section{A. The Inner Workings of Victim-Offender Mediation}

Restorative justice takes many forms, including victim-offender mediation, family group conferencing, and educational programs for offenders. ${ }^{44}$ Among these various programs, victim-offender mediation has emerged as the "most widely developed expression of restorative justice, with more than 25 years of experience and numerous studies in North America and Europe." 45 Over 300 victim-offender mediation and dialogue programs have been established throughout the United States and continue to develop in more than forty-five states. ${ }^{46}$

conferencing. In this program, a trained coordinator, the victim, the offender, and family and friends of the victim meet to discuss how the crime occurred and how it has impacted their lives. Id. at 14. The objective of the conference is "to recognize the harm caused and to decide as a group how the harm will be repaired." Id. Another example of restorative justice programs are community self-help groups such as Mothers Against Drunk Driving (MADD) and Parents of Murdered Children (POMC) which "offer victim panels to speak to offenders about the impact of crime on their lives in order for offenders to develop empathy for what victims have gone through." Id.

43 Id. at 18.

${ }^{44} I d$. at 3 . Both "[v]ictim offender mediation and family group conferences are available for victims who want to have a mediation with the offender to discuss how the crime affected them and how the offender can repair the harm." Id. These programs "are conducted by trained mediators who are sensitive to the needs of victims and their families." Id. Another form of restorative justice are educational programs for offenders, which raise awareness among offenders as to how victims feel and enables offenders to empathize with victims. Id. In addition, "[e]ducation also helps offenders see their responsibilities as members of a community." Id; see also supra note 42.

45 Umbreit, supra note 13 , at 1 . The victim-offender mediation programs are generally referred to as victim-offender mediation and reconciliation programs (VORPs or VOMPs). Price, supra note 26.

46 Umbreit, supra note 13. These figures represent the number of victim-offender mediation programs in the United States only; however, there are about 700 victim- 
The first Victim Offender Reconciliation Project (VORP) was established in Kitchener, Ontario, Canada in 1974 as a small experiment conducted by members of the Mennonite church, as well as a local judge and a probation officer. ${ }^{47}$ The VORP program made its first appearance in the United States in Elkhart, Indiana in 1978.48 The VORP model "was designed to address the needs of the parties in a manner which rendered the justice process meaningful to both, enabling them to resolve the conflict in a manner which they considered appropriate, without court imposition." 49

Since its inception, the use of victim-offender mediation has continued to flourish, as is evidenced by the endorsement that it received from the American Bar Association in 1994.50 Most often employed in cases involving property crimes or minor assaults, 51 victim-offender mediation

offender mediation programs in England, Australia, New Zealand, Eastern Europe, and other countries. VICTIM-OFFENDER RECONCILIATION PROGRAM, ABOUT VICTIMOFFENDER MEDIATION AND RECONCILIATION, at http://www.vorp.com (last visited Oct. 12,2001 ) [hereinafter ABOUT VOM]. Victim-offender mediation programs have become the most familiar form of restorative justice because they manage to address the needs of victims, offenders, and communities, while encouraging reconciliation, promoting offender accountability, and conferring emotional contentment upon victims. Bakker, supra note 13 , at 1519-20 (citing MARK UMBREIT, CRIME AND RECONCILIATION: CREATIVE OpTIONS FOR VICTIMS AND OFFENDERS 101-03 (1985); Tony Dittenhoffer \& Richard V. Ericson, The Victim/Offender Mediation Program: A Message to Correctional Reformers, 33 U. TORONTO L.J. 315, 318 (1985)).

47 Umbreit \& Coates, supra note 14, at 190. The experiment was conducted in response to acts of vandalism by two intoxicated teenagers. Bakker, supra note 13 , at 1483. The two offenders were accompanied by a probation officer and a church volunteer as they met with all "twenty-one victims of vandalism to assess damages and make restitution." Id. (citing Dean E. Peachey, The Kitchener Experiment, in MEDIATION AŃD CRIMINAL JUSTICE: VICTIMS, OFFENDERS AND COMMUNITY 14 (Martin Wright \& Burt Galaway eds., 1989)). Eventually these informal meetings "evolved into an organized victim-offender reconciliation program funded by church donations and government grants and supported by various community groups." Id. (citing Dittenhoffer \& Ericson, supra note 46 , at 316 ). As victims and offenders would meet, their discussion was facilitated by a trained mediator and what started as an experiment soon became "a vision that the 'process of bringing victims and offenders together to reach a mutual agreement regarding restitution [would] become the norm."' Id. (quoting Peachey, supra, at 47).

${ }^{48}$ Umbreit \& Coates, supra note 14, at 191.

${ }^{49} I d$. VORP programs are driven by "the desire to meet the needs of both victims and offenders of crime." Bakker, supra note 13, at 1484. Therefore, the underlying purpose of victim-offender mediation is to engage both victims and offenders in a process in which they actively work to repair any emotional or material harm resulting from the crime. See GUIDELINES, supra note 28, at 1.

50 NAT'L SURVEY OF VOM, supra note 15, at 3.

51 RJ FOR VICTIMS, supra note 4, at 21. Although primarily utilized in cases of property crimes or minor assault, victim-offender mediation programs have become 
programs are frequently found in juvenile courts, law enforcement agencies, probation and corrections departments, and victims' assistance programs. ${ }^{52}$

Generally, there are four phases of the victim-offender mediation process. ${ }^{53}$ The first phase is intake, in which the case is referred to victimoffender mediation and is then pre-screened by the mediator. ${ }^{54}$ The mediator is responsible for contacting both the victim and offender, 55 and if the mediator finds that both parties are eager to negotiate and "show no overt hostility toward each other," the mediator will accept the case for victimoffender mediation. ${ }^{56}$

The next phase is preparation for mediation. ${ }^{57}$ During this phase, the mediator will first arrange individual meetings with each party, in which "the mediator explains the program, answers questions and screens the case for its appropriateness for mediation." 58 In meeting with the victim and offender

useful in dealing with a variety of other crimes "at any stage of the criminal justice process." Price, supra note 26, at 8 . For instance, in cases involving "young offenders and first-time offenders, mediation may be a 'diversion' from prosecution and an opportunity to avoid getting a juvenile or criminal record." Id. In these particular cases, charges against the offender may be dismissed if the offender engages in mediation with the victim in which a mutually acceptable agreement is reached, and the offender "then completes the requirements of the agreement." Id. In those cases in which the offender has pled guilty or the offender has been convicted, "a judge may refer an offender to a victim-offender mediation program as a part of the court's sentence or as a term of probation." Id. Victim-offender mediation has also taken place even after the "offender has been released" from prison. Id.

52 The State of the Art, supra note 32. Generally, victim-offender mediation programs are "operated by either a public agency or the private non-profit section of the community" and "have not, largely, found their way into the area of private practice." Marty Price, Mediated Civil Compromise-A Tool for Restorative Justice, at http://www.vorp.com/articles/civil.html (last visited Oct. 12, 2001) [hereinafter Mediated Civil Compromise].

53 Delgado, supra note 30 , at 756 . A specially trained mediator conducts the entire victim-offender mediation process. Price, supra note 9 , at 10 . Mediators that engage in this process are required to utilize skills beyond the basics of conflict resolution in that they are "trained to guide the sensitive process of preparing victims and offenders to come face to face." Id.

${ }^{54}$ Delgado, supra note 30 , at 756-57.

55 Crime and Punishment, supra note 3 , at 2.

56 Delgado, supra note 30 , at 757.

57 Id.

${ }^{58}$ Crime and Punishment, supra note 3, at 2. These pre-meetings between the mediator and the individual parties "are essential to case development, allowing for thorough preparation of participants to assure safe and successful mediation." Price, supra note 9 , at 10 . These meetings help establish a level of trust between the party and 
separately, "[i]f the mediator does not feel she has effectively established trust and rapport with each of the parties, the case is remanded to court."59 However, if the mediator finds that the case is suitable for mediation and both victim and offender voluntarily agree to participate in the mediation session, the case is ready for mediation..$^{60}$ Preparation for the mediation session may include homework assignments and, in some situations, additional preliminary meetings. ${ }^{61}$

The third phase is the mediation itself. ${ }^{62}$ Mediation sessions are designed to "focus upon dialogue rather than upon reaching a restitution agreement, facilitating empathy and understanding between victim and offender." 63 The mediation session generally begins with an explanation of the ground rules and then the victim is given the opportunity to speak first. ${ }^{64}$ Once the victim has explained to the offender the effects of the offender's crime, the victim may ask the offender questions, and the offender then has an opportunity to "offer an explanation and/or an apology." 65 In the mediation session, the parties are expected to reach a mutually acceptable agreement, "usually a restitution agreement or work order."66 If the parties are unable to reach an agreement the case will be remanded back to the court for further proceedings. 67

The final phase of the victim-offender mediation process is follow-up. ${ }^{68}$ After an agreement is reached during mediation, "the offender's performance and cooperation" is monitored to ensure that he or she is acting in compliance with the work or restitution agreement. ${ }^{69}$

the mediator that is imperative to the success of bringing victims and offenders into dialogue in the mediation session. See id.

59 Delgado, supra note 30, at 757.

60 Crime and Punishment, supra note 3. Participation in a victim-offender mediation program is always voluntary for the victim and in most programs participation is voluntary for the offender as well. Price, supra note 9 , at 9.

61 Crime and Punishment, supra note 3.

62 Delgado, supra note 30, at 757.

63 Crime and Punishment, supra note 3. The victim-offender mediation process is designed to facilitate open dialogue in which participants can address various matters, including issues of forgiveness. Price, supra note 9, at 10.

${ }^{64}$ Crime and Punishment, supra note 3.

65 Id. Commonly asked questions include "Why did you do this to me? Was this my fault? Could I have prevented this? Were you stalking or watching me?" Price, supra note 9 , at 9 .

66 Delgado, supra note 30 , at 757.

67 Id.

$68 \mathrm{Id}$.

69 Id. 
This four-part victim-offender mediation process fully embodies all the ideals of the restorative justice concept. Operating under a pure restorative justice theory, this four-stage process provides a secure setting in which victims and offenders can communicate and work together to devise a mutually acceptable plan, obtain answers to questions, and discuss the impact of the offender's behavior. ${ }^{70}$

\section{B. Advantages and Statistically Proven Beneficial Effects of Victim- Offender Mediation}

The advantages of engaging in victim-offender mediation are numerous. One of the principal benefits of victim-offender mediation programs "is that they humanize the criminal justice process." 71 When offenders are brought face-to-face with their victims, the harm they have caused becomes very real, making it extremely "difficult for the offenders to rationalize their criminal behavior."72 Furthermore, by learning that the victim is no longer nameless or faceless, it is hoped that this face-to-face interaction will instill in the offender a sense of compassion for the victim, hence making it more difficult for the offender to replicate his wrongdoings in the future. ${ }^{73}$ Another important benefit which victim-offender mediation provides to the offender is emotional and psychological release from the stigma of being labeled a criminal. ${ }^{74}$ The overall benefit of victim-offender mediation programs, as indicated by its proponents, is that these programs "will empower the victim while reducing recidivism among offenders." 75 The underlying hope of

70 U.S. DEP'T OF Justice, Restorative Justice FACT SheET 11, http://ssw.che.umn.edu/rjp/resources/documents/USDOJ97A.pdf (last visited Oct. 8, 2001) [hereinafter DOJ/FBI FACT SHEET].

71 VICTIM-OFFENDER RECONCILIATION PROGRAM INFORMATION AND RESOURCE CENTER, VICTIM-OFFENDER MEDIATION/DIALOGUE PROGRAMS, at http://www.vorp.com/articles/abaendors.html (last visited Oct. 12, 2001) [hereinafter VOM/DIALOGUE PROGRAMS].

${ }^{72} \mathrm{Id}$. Generally, "[v]ictims of property crime are quite willing to participate in a mediation session with their offenders when given the opportunity." MARK. S. UMBREIT, MEDIATING INTERPERSONAL CONFLICTS 155-56 (1995).

${ }^{73}$ Cottam, supra note 16, at 1537.

${ }^{74}$ Mediated Civil Compromise, supra note 52. Releasing the offender from this selfimage of being stigmatized as a criminal "is not typically experienced after punishment without restitution and reconciliation." $I d$.

75 Delgado, supra note 30 , at 758 . In victim-offender reconciliation programs throughout the United States recidivism rates are reported as being "under $10 \%$ for offenders who have been through [the program]," as compared to the typical recidivism rates of fifty to eighty-five percent. Mediated Civil Compromise, supra note 52. 
victim-offender mediation programs is that both victims and offenders will gain a greater understanding of "each other's common humanity and that offenders will be able to take their place in the wider community as valued citizens." 76

Research conducted on victim-offender mediation indicates an end result in which both victims and offenders are left with a greater sense of satisfaction for both the program and the justice system as a whole. ${ }^{77}$ The largest multi-site study of VORP programs was conducted in 1994 by Dr. Mark Umbreit. ${ }^{78}$ The results of this study provide an excellent overview as to the consensus among victims and offenders about the victim-offender mediation process and the effectiveness of these programs. During a twoyear period, 3142 cases were referred to one of four programs. Of those sessions, ninety-five percent resulted in a successful restitution agreement. ${ }^{79}$ For victims, there was much greater satisfaction with the mediation process (seventy-nine percent) as opposed to the normal court procedure (fifty-seven percent). ${ }^{80}$ Additionally, after engaging in mediation, victims were considerably less apprehensive about being re-victimized. ${ }^{81}$ For offenders,

${ }^{76}$ Delgado, supra note 30, at 758.

77 VOM/DIALOGUE PROGRAMS, supra note 71 . Those victims who participate in mediation are more likely to perceive the justice system as fair compared to similarly situated victims who do not choose to engage in mediation. UMBREIT, supra note 72 , at 157. Furthermore, a 1989 study evaluating four victim-offender reconciliation programs in Indiana identified the aspects of mediation that both victims and offenders alike found most satisfying. Victims indicated that the most gratifying aspects of mediation were "(1) the opportunity to meet the offender in order to obtain a better understanding of the crime and of the offender's situation; (2) the opportunity to secure restitution; (3) the offender's expression of remorse; (4) the care and concern of the mediator." Umbreit \& Coates, supra note 14, at 192-93. For the offender, the most satisfying features of the process were "(1) meeting the victim and discovering that the victim was willing to listen to them; (2) staying out of jail and in some instances escaping a criminal record; (3) the opportunity to work out a realistic schedule for restitution and 'make things right." Id. at 193.

${ }^{78}$ CRJ FACT SHEET, supra note 31. Dr. Mark Umbreit is a professor at the University of Minnesota School of Social Work, and is the founding Director of the Center for Restorative Justice \& Peacemaking and the National Restorative Justice Training Institute. CTR. FOR RESTORATIVE JUSTICE \& PEACEMAKING, at http://ssw.che.umn.edu/rjp/People/Umbreit.htm (last visited Oct. 8, 2001). Dr. Umbreit "is an internationally recognized practitioner and scholar with more than 28 years of experience as a mediator, trainer, researcher and author" Id. Dr. Umbreit's 1994 study examined programs specifically involving juvenile offenders in four different cities. CRJ FACT SHEET, supra note 31.

$79 \mathrm{Id}$.

${ }^{80} \mathrm{DOJ} / \mathrm{FBI}$ FACT SHEET, supra note 70, at 12.

81 CRJ FACT SHEET, supra note 31. 
the study indicated a much greater sense of accountability among those who engaged in victim-offender mediation, as well as lower recidivism rates. ${ }^{82}$

\section{The Scope of Victim-Offender Mediation}

Victim-offender mediation programs may not be appropriate for every victim and offender. ${ }^{83}$ Therefore, it is imperative that cases are screened on an individual basis to determine whether they are suitable for mediation. ${ }^{84}$ Victim-offender mediation programs are most consistently utilized in cases ranging from property crimes to minor assaults, or any other crimes that would not result in receiving prison time. ${ }^{85}$

Recently, the trend in victim-offender mediation has been "toward deepening the process and expanding its scope." 86 Although it has not been commonplace in the past, there is a greater movement toward mediating

82 Offenders who engaged in mediation "were far more likely to successfully complete their restitution obligation to the victim (eighty-one percent), than similar offenders who did not participate in a victim offender mediation session (fifty-eight percent)." CRJ FACT SHEET, supra note 31. In addition, "[f]ewer offenders who participated in victim offender mediation recidivated (eighteen percent) than similar offenders who did not participate in mediation (twenty-seven percent)." DOJ/FBI FACT SHEET, supra note 70, at 12.

${ }^{83}$ For instance, victim-offender mediation programs are generally used for crimes committed by first and second-time juvenile offenders. Delgado, supra note 30, at 757 . Therefore, while victim-offender mediation programs may be deemed most appropriate in dealing with juvenile crime, there are some programs that do cater to adult felons, such as rapists and alleged killers. Id. However, not all adult crime may be suitable for victimoffender mediation and it is important that each case be individually screened before going to mediation. Mediated Civil Compromise, supra note 52.

${ }^{84}$ Mediated Civil Compromise, supra note 52. There are no set guidelines as to which cases will go to mediation and which ones will not. Id. When deciding whether to refer a case to mediation, some specific factors to consider are: offenders who seem to be accepting responsibility for the crime, an offender who is open to the idea of talking to the victim and working out a restitution plan, and a situation involving some loss or harm which can be mediated. Id.

${ }^{85}$ Cottam, supra note 16 , at 1536 . In a 1996 survey of victim-offender mediation programs conducted by the Center for Restorative Justice \& Mediation at the University of Minnesota School of Social Work, the three most common cases submitted to victimoffender mediation, "in order of frequency, [were] vandalism, minor assaults, and theft." NAT'L SURVEY OF VOM, supra note 15, at 5-7.

${ }^{86}$ The State of the Art, supra note 32. Many programs have been reporting a trend in mediating cases involving higher levels of crime. NAT'L SURVEY OF VOM, supra note 15, at 16. These cases often entail a greater amount of violence and tend to be committed by offenders with a considerable number of prior convictions. Id. 
crimes of severe violence. ${ }^{87}$ In cases involving violent crime, victim-offender mediation does not serve as a substitute for punishment. ${ }^{88}$ However, it does offer a means of healing and a sense of closure that cannot be achieved by punishment alone. ${ }^{89}$ Both "victims and survivors of severely violent crimes, including murders and sexual assaults, are finding that confronting their offenders in safe and controlled settings, with the assistance of the mediator, returns their stolen sense of safety and control in their lives." 90

In a case of a young man who was robbed and shot in the head by a man who had previously assaulted two other men in the area, the victim's mother engaged in victim-offender mediation. ${ }^{91}$ The woman spent ten months preparing for the mediation with an experienced mediator and finally after nine years she was able to come face to face with her son's killer in a high-

${ }^{87}$ Crime and Punishment, supra note 3. There exists a growing number of programs in which rapes and other violent assaults are being mediated. The State of the Art, supra note 32. In addition, there have beer. several mediations between murderers and the family members of the murder victims. Id. In cases involving extremely violent crimes, victim-offender mediation is generally employed "at the request of the victim(s) or a surviving family member." UMBREIT, supra note 72, at 163 . In these types of cases, mediation will only take place "after many months (sometimes even years) of work with a specially trained and qualified mediator, collaborating with the victim's therapist and/or other helping professionals." Crime and Punishment, supra note 3. Moreover, it is essential that participation is "completely voluntary, for both victim and offender." $I d$. In determining whether a case of severe violence should go to mediation, mediators are responsible for thoroughly screening cases. Id. Victim safety is a crucial consideration for mediators during the screening process as well as every aspect of the mediation process. Id. It is "[o]nly [those] offenders who admit their guilt, express remorse and want to make amends [who] are candidates for mediation." Id.

${ }^{88}$ Price, supra note 26. For instance, it is rare that judges will "reduce prison sentences as a result of mediation." $I d$.

${ }^{89}$ Crime and Punishment, supra note 3. Victim-offender mediation presents victims of severe violence the opportunity to offer forgiveness to the offender, which for some "is an important and powerful act of inner spiritual strength, of letting go, regardless of the impact on the offender." UMBREIT, supra note 72, at 154.

90 Crime and Punishment, supra note 3. Mediation has increasingly been used in cases involving drunk-driving fatalities so as to aid in the reparation of the lives of surviving family members and victims. Id. Victim-offender mediation has also been used in a variety of other circumstances. For instance, in a case involving a woman who decided to engage in victim-offender mediation after having been raped, the woman found it extremely helpful to directly confront the source of terror in her life. UMBREIT, supra note 72 , at 149 . After the mediation "[s] he felt less fearful and more able to let go of the terror she had undergone." Id.

91 UMBRETT, supra note 72, at 148. 
security prison. ${ }^{92}$ The woman felt that the victim-offender mediation process was "a pivotal moment in her long journey of grieving and her search for closure." 93 In this particular case, the woman felt that "she needed to let the man who killed her son know the devastating effect the crime had on her life, and to get answers to many questions."94 Victim-offender mediation may not be appropriate for all victims of crimes of severe violence, but it has continually proven beneficial in cases such as these in which it has been employed..$^{95}$

\section{HATE CRIMES}

Those who are bigots do not stop at classes, at races, or again, at gays and lesbians. Those who hate you, hate me. Those who hate, hate everybody. Hate is contagious.... No one has the right not to allow you to acquire the dignity, the respect, and the self-respect to which we are all entitled. ${ }^{96}$

For centuries, hate crimes have played a crucial role in shaping world history. ${ }^{97}$ In the United States, hate crime is not a new phenomenon. ${ }^{98}$ For

92 Id. When mediation is utilized in a murder case such as this or any other situation in which a crime of severe violence has been committed, the mediation will have distinguishing characteristics. Id. at 151 . These include

[e]motional intensity; [e]xtreme need for nonjudgmental attitude; [1]onger case preparation by mediator (six to eighteen months); [m]ultiple separate meetings prior to joint session; [m] ultiple phone conversations; [n]egotiation with correctional officials to secure access to inmate and to conduct mediation in prison; [c]oaching of participants in the communication of intense feelings; and [b]oundary clarification (mediation versus therapy).

Id.

93 Id. at 148 .

$94 \mathrm{Id}$. at 149 .

$95 \mathrm{Id}$. at $148-49$.

96 Charles G. Brown, First Get Mad, Then Get Justice 161 (1993) (quoting Elie Wiesel, Jewish writer and Holocaust survivor).

97 NCJA, supra note 19, at ix. Some prominent examples of hate crime throughout the world have included "the Romans' persecution of Christians and the Nazis' 'final solution' for the Jews [as well as] 'ethnic cleansing' in Bosnia and genocide in Rwanda ...."Id.

98 Throughout history, hate groups have existed in the United States. In 1999, there were a total of 457 established hate groups in the United States. National Center for Victims of Crime, Statistics, at http://www.ncvc.org/stats/hc.htm (last visited Oct. 12, 2001) [hereinafter NCVC]. Of that total number of hate groups, "138 can be categorized as Ku Klux Klan groups, 130 as Neo-Nazis, 40 as Racist Skinheads, 46 as Christian Identity groups, 21 as Black Separatists, and the remaining 82 as other." Id. 
years, hate crimes have been prevalent in the United States, particularly those inspired by religious and racial biases. ${ }^{99}$

Hate crimes distinguish criminal behavior prompted "by prejudices from criminal conduct motivated by lust, jealousy, greed, politics, and so forth."100 Unlike other criminal offenses, hate crimes accentuate the underlying attitudes, values, and character of individual offenders. ${ }^{101}$ Congress has defined hate crime as that "in which the defendant intentionally selects a victim, or in the case of a property crime, the property that is the object of the crime, because of the actual or perceived race, color, national origin, ethnicity, gender, disability, or sexual orientation of any person."102

Among those individuals participating in incidents of hate crime, juveniles and other young people tend to be disproportionately represented. ${ }^{103}$ There is a host of factors that may incite these otherwise law-

${ }^{99} \mathrm{NCJA}$, supra note 19 , at xi. Typically, the most common types of hate crimes that occur in the United States "include the lynchings of African Americans, cross burnings to drive black families from predominately white neighborhoods, assaults on homosexuals, and the painting of swastikas on Jewish synagogues." Id. Specifically, in 1999, the Federal Bureau of Investigation (FBI) reported a total of 7,876 bias-motivated criminal incidents. U.S. DEP'T OF JUSTICE, FED. BUREAU OF INVESTIGATÍON, 1999 HATE CRIME STATISTICS 5 (1999), at http://www.fbi.gov/ucr/99hate.pdf [hereinafter DOJ/FBI HATE CRIME STATS]. Of the 7876 incidents there were "9,301 separate offenses, 9,802 victims, and 7,271 known distinguishable offenders." Id. Of the 9301 offenses reported in 1999, sixty-seven percent were crimes against persons. Id. Of all the offenses reported in 1999, the most common were intimidation (3268 or thirty-five percent); destruction/damage/vandalism of property (2654 or twenty-nine percent); simple assault (1766 or nineteen percent); and aggravated assault (1120 or twelve percent). Id. at 5,9 . In addition, the FBI reported seventeen murders and six forcible rapes as a result of hatemotivated incidents. Id. at 9 . Of those seventeen murders, "racial bias motivated 9 of the murders; sexual-orientation bias and ethnicity/national origin bias each, 3 ; and religious bias, 2." Id. at 5 .

100 James B. Jacobs \& Kimberly A. Potter, Hate Crimes: A Critical Perspective, 22 CRIME \& JUST. 1, 2 (1997). Prejudice is generally defined as a "'negative attitude or opinion about a particular group or class of people."' $I d$. at 3-4.

101 Id. at 2.

102 Violent Crime Control and Law Enforcement Act of 1994, Pub. L. 103-322, $\S 280003$, 108 Stat. 1796 (1994) (codified at 28 U.S.C. $\S 994$ note (1994) (Enhanced Penalty for Hate Crimes)). Under the Hate Crime Statistics Act, Pub. L. 1030322, title XXXII, § 320926, 108 Stat. 2131 (1994) (codified at 28 U.S.C. § 534 note (1994) (Hate Crime Statistics)) hate crimes are defined as "crimes that manifest evidence of prejudice based on race, religion, sexual orientation, or ethnicity, including where appropriate the crimes of murder, non-negligent manslaughter, forcible rape, aggravated assault, simple assault, intimidation, arson and destruction, damage or vandalism of property."

103 NCJA, supra note 19 , at 13 . Nationwide, "slightly more than one-quarter of all crimes are committed by people younger than 20 years old, but about half of all hate crimes are estimated to be committed by people younger than $20 . "$ Id. 
abiding individuals to engage in hate crimes. Some of these crimes are fueled by alcohol and drugs; however, more often then not "the main determinant appears to be personal prejudice, a situation that colors people's judgment, blinding the aggressors to the immorality of what they are doing."104 Other factors that may lead individuals to commit hate crimes include racial stereotypes, individual incidents with members of a certain minority group, and tentative economic conditions. ${ }^{105}$ Regardless of the contributing factors, "[o]nce a climate of hate is created, a single incident-such as the videotaped beating of Los Angeles, California, motorist Rodney King-can trigger a wave of hate crimes."106

Those criminal acts which are prompted by prejudice, "may carry far more weight" than the average criminal offense because hate crimes reach beyond the victimization of a single target. ${ }^{107}$ When a hate crime occurs, it victimizes "every member of the group that the immediate target

104 Position Paper, Am. Psychological Ass'n, Hate Crimes Today: An Age-Old Foe In Modern Dress (1998), at http://www.apa.org/pubinfo/hate/homepage.html [hereinafter APA Position Paper].

105 NCJA, supra note 19, at x. Additional factors include "racial stereotypes in films and on television, hate filled discourse on talk shows or in political advertisements, the use of racial code language such as 'welfare mothers' and inner city thugs ..." Id. For example, in recent months Music Television (MTV) has come under fire for "help[ing] controversial rapper Eminem become a household name." Dan Harris, Music on Hold, Abcnews.com (Jan. 10, 2001), at http://more.abcnews.go.com/sections/entertainment/Dai lyNews/mtv010110.html. Eminem has become known for his ferocious song lyrics, such as " $[\mathrm{m}] \mathrm{y}$ words are like a dagger with a jagged edge [t] $]$ hat'll stab you in the head whether you're a fag or lez [o]r the homosex, hermaph or a trans-a-vest [p]ants or dress - hate fags? The answer's 'yes' Homophobic?" EMINEM, Criminal, on THE MARSHALL MATHERS LP (UNI/INTERSCOPE 2000), http://www.geocities.com/lyricseminem/marsh all_lyrics/criminal.html. Eminem's lyrics have stirred concern amongst parents, lawmakers and The Gay and Lesbian Alliance Against Defamation who find the lyrics to be blatantly offensive. Was the Defiant Rapper's Bestselling LP a Poetic Masterpiece or a Musical Hate Crime?, PEOPLE MAG., Dec. 25, 2000, at 64. Through his lyrics Eminem is sending a message to his young fans that biases against certain groups of people, particularly gays and lesbians, are acceptable. It is lyrics such as these and the influence they may have on those who listen to the music that perpetuates feelings of animosity toward certain groups of people and continues to spur incidents of hate crimes in today's society. Additionally, other modes of communication have emerged, such as the Internet, which provides yet another avenue for conveying feelings of hate toward specific groups of individuals. As of early 2000 there were a total of 305 hate based websites on the Internet. NCVC, supra note 98.

106 NCJA, supra note 19 , at $\mathrm{x}$.

107 Id. 
VICTIM-OFFENDER MEDIATION

represents,"108 sending "fear and discomfiture across [an entire] community."109

\section{PReVAiling HAte CRIMEs In AMERICA}

Despite paramount efforts by both "political and community leaders to foster tolerance and understanding, deep-seated racial tensions continue to plague the Nation." 110 Bias-motivated crimes continue to fill the pages of many of the United States' most influential newspapers. ${ }^{111}$ In particular, this

108 Id. at 21.

109 Id. "Hate crimes are message crimes" in that they send a particular "message to members of a certain group that they are unwelcome in a particular neighborhood, community, school or workplace." APA Position Paper, supra note 104, at 5.

110 NCJA, supra note 19, at ix. In the wake of the September 11, 2001 terrorist attacks on America, hate crimes "have risen exponentially across the U.S." CNN.com, Hate Crime Reports up in Wake of Terrorist Attacks, at http://asia.cnn.com/2001/US/09/16/gen.hate.crimes/index.html (Sept. 17, 2001). The Council on American Islamic Relations (CAIR) says that since the occurrence of the terrorist events "it ha[s] received reports of harassment of Muslim women and obscenities shouted on the street; bombings, car rammings and arson attempts at mosques; and beatings, death threats and possibly even killings." CNN.com, Bush Denounces Muslim Harassment, at http://asia.cnn.com/2001/US/09/17/gen.hate.crimes/ (Sept. 18, 2001). Members of the Muslim community are not the only ones experiencing such raciallymotivated attacks. Other groups such as the "Indian Sikh community say they are being targeted because their men wear turbans and long beards as part of their religious dress, a tradition that's lasted for 500 years." CNN.com, Hate Crime Reports up in Wake of Terrorist Attacks, at http://asia.cnn.com/2001/US/09/16/gen.hate.crimes/index.html (Sept. 17, 2001). In an effort to deter the occurrence of such incidents against Muslim Americans and others, President Bush has denounced these actions stating that "[t]hose directing their anger against Muslims in the wake of the terrorist attacks on the World Trade Center and the Pentagon should be 'ashamed."' CNN.com, Bush Denounces Muslim Harassment, at http://asia.cnn.com/2001/US/09/17/gen.hate.crimes/ (Sept. 18; 2001). In addition, the Federal Bureau of Investigation (FBI) has proclaimed that it will not tolerate such "attacks and threats against Arab-Americans" and has "committed to investigating and prosecuting violations of federal hate crime laws." Id. Since the events on September $11^{\text {th }}$, the FBI has responded to various reports of "attacks against ArabAmerican citizens and institutions" and so far it has initiated at least " 40 hate-crime investigations." Id.

111 Id. In the mid-1990s, there were a disproportionate number of fires occurring at black churches, which indicated to many of the Nation's leaders "that the Nation was experiencing a serious wave of hate crimes." Id. When discussing occurrences such as these, it is imperative to distinguish between hate crimes and hate incidents. "A hate incident is any act, whether consisting of conduct, speech, or expression, to which a bias motive is evident as a contributing factor, without regard for whether the act constitutes a crime." Stop The Hate.org, Hate Crimes vs. Hate Incidents, at http://www.stopthehate.or g/get_involved/law/empower/crimes_vs_incidents.php (last visited Oct. 13, 2001). 
nation has encountered a tremendous surge in the occurrence of extremely disturbing and even deadly hate crimes. ${ }^{112}$

Hate crimes are committed for a plethora of reasons, including acts against one's race, ethnicity, religion, gender, disability, and sexual orientation. Historically, the brunt of hate crime has fallen upon some classifications more than others. ${ }^{113}$ However, since the mid-1980s the issue of hate crimes in the United States has stirred "mounting public scrutiny,"114 primarily resulting from numerous bias motivated incidents involving race, religion, and sexual orientation. ${ }^{115}$

\section{A. Crimes Committed on the Basis of Race}

Racial bias is "[b]y far the largest determinant of hate crimes"116 affecting African Americans, Asian/Pacific Islanders, Native Americans, and Caucasians alike. ${ }^{117}$ Although different races have fallen pray to hate crimes, African Americans seem to be the group at greatest risk. ${ }^{118}$

Therefore, although motivated by bias, it is important to recognize that not every hate incident constitutes a criminal act. Id. Hate incidents "become [hate] crimes only when they directly incite perpetrators to commit violence against persons or property, or if they place a victim in reasonable fear of physical injury." $I d$.

112 WESSLER, supra note 18, at 1 . There is a growing "consensus among journalists, politicians, and academics that the United States is experiencing an unprecedented 'hate crime epidemic."' Jacobs \& Potter, supra note 100, at 13.

113 NCJA, supra note 19, at 14. African Americans have historically endured the most substantial burden of hate crimes. Id.

$114 \mathrm{Id}$. at 1.

115 For instance, the FBI's 1999 Hate Crime Statistics found that 4295 (fifty-five percent) of the hate crime incidents were motivated by racial bias; 1411 (eighteen percent) by religious bias; 1317 (seventeen percent) by a bias against sexual orientation; 829 (eleven percent) by a bias against ethnicity or national origin; nineteen by bias against disability; and five were multiple-bias incidents. DOJ/FBI HATE CRIME STATS, supra note 99.

116 APA Position Paper, supra note 104. For instance, in 1999, 4295 out of the 7876 hate crimes reported to the FBI, were promulgated because of race, with 2958 (sixty-nine percent) specifically targeting African Americans. DOJ/FBI HATE CRIME STATS, supra note 99.

117 According to the 1999 DOJ/FBI Hate Crime Statistics, there were 2958 hate crime incidents committed against African Americans, 298 against Asian/Pacific Islanders, forty-seven against American Indian/Alaskan Native, and 781 against Whites. DOJ/FBI HATE CRIME STATS, supra note 99.

118 APA Position Paper, supra note 104. In 1994, "[n]early 4 out of every 10 hate crime incidents ... were classified as 'anti-black." NCJA, supra note 19, at 14. 
Historically, violence against African Americans has been viewed as the quintessential hate crime because a crime against an African American not only injures individuals, but also serves as a means of intimidating an entire group of people. ${ }^{119}$ Since the Nineteenth Century, African Americans have been the victims of cross burnings, church bombings, and murder. ${ }^{120}$

One of the most heinous illustrations of hate crimes committed against blacks in recent years was the dragging death of James Byrd, Jr., forty-nine, of Jasper, Texas in June of 1998.121 Byrd, a disabled black man, was returning from a family party when three men offered him a ride. ${ }^{122}$ The men took Byrd outside of town, chained him by his ankles and tied him to the back of a pickup truck. ${ }^{123}$ They then proceeded to drag Byrd along an old logging road until his head and arm ripped apart from his body. ${ }^{124}$ Within twenty-four hours of committing this odious crime, the three men, having ties to white supremacy groups, were arrested.125 Tensions began to rise in the aftermath of this racially charged crime. The New Black Panthers came into town to advise the black residents to arm themselves and the $\mathrm{Ku}$ Klux Klan announced that it would begin rallying in the town square. ${ }^{126}$ The community as a whole was traumatized, suffering a deep-rooted emotion that would take a great deal of time and effort to mend. ${ }^{127}$

119 UMBREIT, supra note 72, at 1.

${ }^{120}$ APA Position Paper, supra note 104.

121 Id. at 3.

122 The three men were John William King, age twenty-four, Shawn Berry, age twenty-four, and Lawrence Brewer, age thirty-one. Joseph L. Galloway, Into the Heart of Darkness, U.S. NEWS \& WORLD REP., Mar. 8, 1999, at 18.

${ }^{123}$ Dan McGraw, Justice Delayed, U.S. NEwS \& WORLD REP., Mar. 1, 1999, at 28.

${ }^{124} \mathrm{Id}$.

125 Dan McGraw, A Texas Town Heals Its Wounds, U.S. NEWS \& WORLD REP., Oct. 26,1998 , at 24.

$126 \mathrm{Id}$.

127 Several days after the killing, Reverend Jesse Jackson came to Jasper to address a church service. McGraw, supra note 125, at 24. Jasper officials, black and white, maintained "a united front, condemning the hate messages from all sides." Id. Months after the killing, a series of town meetings were held to discuss possible measures that could be taken to ease mounting racial tensions. Id. Most recently, as a result of this incident, Texas has enacted the James Byrd Jr. Hate Crimes Act. Helen Norton, Texas Governor Signs Hate Crimes Law, at http://www.civilrights.org/library/detail.cfm?id=3515 (May 31, 2001). The Act was signed into law on May 11,2001, and it "toughens penalties for crimes motivated by the victim's race, religion, color, sex, disability, sexual orientation, age or national origin." Id. 


\section{B. Crimes Committed on the Basis of Religion}

Attacks upon individuals and institutions on the basis of religion are another highly concentrated source of hate crimes. Religiously motivated hate crimes are generally signified by acts of vandalism and at times even personal attacks. ${ }^{128}$ The overwhelming majority of these incidents are targeted at the Jewish religion. 129

Prejudice against Jews is not a new phenomenon for it has long persisted as a problem in the United States. ${ }^{130}$ Jews have continually been excluded "from attending certain schools, entering certain professions, holding certain jobs, or moving into certain neighborhoods."131 Incidents of hate crimes targeting Jews range from property crimes to physical assault upon individuals. ${ }^{132}$ In the instances in which property crimes have been committed, they typically involve acts of vandalism. ${ }^{133}$ For example, in 1997 the University of Chicago library discovered anti-Semitic graffiti such as SS lightning bolts and swastikas on several Hebrew and Yiddish books. ${ }^{134}$

Although most incidents against the Jewish religion have involved the desecration "of synagogues and cemeteries and the painting of swastikas on private homes," physical assaults are not atypical. ${ }^{135}$ In addition, many Jews as individual members of society have been subjected to anti-Semitic comments. For instance, a fourteen-year-old boy in Gloucester, Massachusetts utilized the Internet to send a series of anti-Semitic death threats to his school teacher. ${ }^{136}$ Among the messages received by the teacher,

128 APA Position Paper, supra note 104.

129 Id. In 1999, the FBI reported that seventy-nine percent of all religiously provoked hate crimes were directed against people of the Jewish faith. DOJ/FBI HATE CRIME STATS, supra note 99.

130 APA Position Paper, supra note 104, at 7. Abomination towards Jewish people "is fed by slanders and stereotypes that have their origins in Europe extending back for centuries." Civilrights.org., Faces of Hate Crimes: Attacks on Jews, at $\mathrm{http} / /$ www.civilrights.org/programs/hate_crimes/faces/index.html (last visited Oct. 13, 2001) [hereinafter Faces of Hate Crimes].

131 APA Position Paper, supra note 104. Similarly, many African Americans and Catholics have also been barred from some of these same opportunities. Id.

132 Id.

133 Id.

${ }^{134}$ Id. at 7 . Another example of property crime committed against Jews occurred at a Jewish Center in New York City where an explosive device was placed at the door and detonated. Id.

135 Faces of Hate Crimes, supra note 130.

136 "Stop the Hate!" Campus Hate Crime Prevention Program, Incidents of Hate Crime, at http://www.stophate.org (last visited Oct. 13, 2001) (on file with author). 
one communication simply stated, "[y] and your body shot full of holes." 137

In August 1991, the United States experienced one of the most dramatic occurrences of anti-Semitic hate crimes in recent history. ${ }^{138}$ The incident transpired in the Crown Heights section of Brooklyn. ${ }^{139}$ In a motorcade for Grand Rabbi Menachem Scheerson, a car driven by a Hasidic Jew unintentionally swerved onto the sidewalk, tragically killing a black youth. ${ }^{140}$ The death of this young boy was followed by four days of intense rioting in which, "[c]hanting 'kill the Jews,' mobs set fires, destroyed property, and looted stores, and assaulted and harassed citizens." 141

Several hours after the tragic incident and in the midst of all the rioting, Yankel Rosenbaum, a twenty-nine-year-old rabbinical student, was murdered. ${ }^{142}$ Rosenbaum was spotted by a group of African Americans who yelled, "There's a Jew' and 'Get the Jew." 143 Rosenbaum was surrounded by a fifteen-member mob that proceeded to beat and stab him. ${ }^{144}$ The act committed against Rosenbaum was "one of blind, baseless bigotry and putrid violent hate,"'145 and although the man responsible for stabbing Rosenbaum was acquitted on criminal charges, he was eventually convicted for violating Rosenbaum's civil rights. ${ }^{146}$

\section{Crimes Committed on the Basis of Sexual Preference}

Although racial and religious prejudice remain prominent sources of hate crimes in this country, incidents involving sexual orientation have become

137 Id.

138 Jacobs \& Potter, supra note 100, at 24.

139 Id.

140 Stephen M. Kocis, III, Crown Heights: Too Little, Too Late, at http://www4.allencol.edu/ smk0/ftt/ftr-021697.html (Feb. 16, 1997).

141 Jacobs \& Potter, supra note 100, at 24.

142 Kocis, supra note 140.

143 Id.

144 Id.

145 Debra Nussbaum Cohen, Crown Heights Sentence Still Leave [sic] Void for Family, JEWISH TELEGRAPHIC AGENCY, Mar. 31, 1998, http://www.jta.org/story.asp?story=1193 (quoting Fay Rosenbaum, the victim's mother).

146 Lemerick Nelson, Jr. originally confessed to having killed Rosenbaum, but later retracted his confession, saying that it was coerced. Kocis, supra note 140 . The jury retumed a verdict of not guilty on the criminal charges. Id. After the acquittal, Rosenbaum's brother then pressed federal officials to charge Nelson for violating his brother's civil rights. Cohen, supra note 145. 
increasingly prevalent in today's society. ${ }^{147}$ Hate crimes targeting sexual minorities have become socially tolerable and are perhaps the most rampant "form of hate crime among teenagers and young adults."148

Statistically, it is evident that attacks upon sexual minorities are dramatically increasing. What is more alarming, however, is the severity of these attacks. ${ }^{149}$ Crimes against gays and lesbians are becoming more and more violent as is evidenced by some of the heinous acts that have occurred in recent years. ${ }^{150}$ For instance, in March of 1992 the lesbian and gay organizations' office at Northeastern University in Boston received a telephone call from an anonymous male student who threatened to blow up the office as well as kill all the members of the group. ${ }^{151}$ This particular incident is reminiscent of many of the early types of hate crimes committed against sexual minorities.

In the past several years, however, the United States has witnessed crimes against sexual minorities that are shocking the nation due to their extreme insensitivity and caliber of brutality. In October of 1998, the death

147 Hate crimes committed "against gays (including bisexuals) increased 51 percent in 1995 compared with the previous year, from 663 to 1,002 incidents." NCJA, supra note 19 , at 19.

148 APA Position Paper, supra note 104 (quoting Dr. Karen Franklin). For instance, in 1999, "[o]ver four-fifths of the perpetrators of anti-gay, -lesbian, -bisexual, and -transgender incidents were male, and two-thirds were under the age of 30 ." NCVC, supra note 98.

${ }^{149}$ Faces of Hate Crimes, supra note 130 . In 1995, "[n]early $40 \%$ of total incidents [committed against sexual minorities] involved physical assaults or attempted assaults with a weapon." Id. In addition, "there were 29 gay-related murders" that year. Id.

150 In the past few years there have been several anti-gay incidents that have received national attention. See generally HateCrime.org, at http://hatecrime.org/ (last visited Oct. 13, 2001). On July 4, 2000, Arthur "J.R." Warren, twenty-six, was brutally beaten to death by two teenagers in West Virginia because he was gay. See Lawrence Messina, Teens Admitted to Attack on Gay Marion Man, The CHARLESTON GAzeTTE, Sept. 19, 2000, at A1. After beating up Warren, the teenagers drove him to a rural road where they drove over him twice with a car. Id. On July 5, 1999, Private First Class Barry Winchell, twenty-one, was bludgeoned to death with a baseball bat by fellow service members while asleep on his cot because they suspected that he was gay. See Mark Thompson, "Why Do People Have to Push Me Like That?", TiME, Dec. 13, 1999, at 56. On December 31, 1993, at the age of twenty Teena Brandon, also known as Brandon Teena, was shot to death and stabbed by two men. Gwendolyn Ann Smith, Remembering Our Dead, at http://www.gender.org/remember/people/brandonframe.html (last visited Oct. 12, 2001). Brandon, born and raised as a girl, was living as a man when two men, seeking to prove that Brandon was really a woman, "kidnapped, raped, and assaulted Brandon." Id. After reporting the rape, Brandon was later shot and killed by these same two men. Id.

151 Incidents of Hate Crime, supra note 136. 
of Matthew Shepard, a gay college student, in Laramie, Wyoming received national attention. ${ }^{152}$ Shepard was lured from a bar by two men who robbed him, brutally beat him with a pistol, and then tied him to a fence where he was left to die. ${ }^{153}$ With a smashed skull, Shepard was roped to the fence for close to eighteen hours in near-freezing temperatures before passersby discovered him. ${ }^{154}$ By the time he got to a hospital his chances of living were slim, and as a result of severe damage to his brain stem he died five days later. ${ }^{155}$

Comparable to the fatal beating of Matthew Shepard was the February 1999 brutal murder of thirty-nine-year-old Billy Jack Gaither. ${ }^{156}$ Two men, angry over an alleged sexual advance made by Gaither, took Gaither to the banks of a creek where they beat him to death with an ax handle and then proceeded to burn his body on top of a set of tires. ${ }^{157}$

152 Howard Chua-Eoan, That's Not A Scarecrow, TIME, Oct. 19, 1998, at 72.

153 Tom Kenworthy, Gay Man Near Death After Beating, Burning, WASH. POST, Oct. 10, 1998 at A1; Chua-Eoan, supra note 152, at 72. Both of the men responsible for committing the acts against Shepard, Aaron McKinney, twenty-two, and Russell Henderson, twenty-one, were charged with first-degree attempted murder. Kenworthy, supra, at A1. Henderson pleaded guilty to both the murder and kidnapping charges, receiving two consecutive life sentences. Id. McKinney was given two life sentences for felony murder, aggravated robbery, and kidnapping. Scott D. McCoy, Note, The Homosexual-Advance Defense and Hate Crimes Statutes: Their Interaction and Conflict, 22 CARDOZO L. REV. 629, 631 n.11 (2001).

154 Chua-Eoan, supra note 152, at 72.

155 See Lisa Meyer, The Hidden Hate Epidemic, ADVOC., May 25, 1999, at 61-62.

156 Sue Anne Pressley, 2 Accused of Killing, Burning Gay Man, WASH. POST, Mar. 5,1999 , at A1. This incident occurred in Sylacauga, Alabama. The two offenders, Steven Mullins, twenty-five, and Charles Butler, Jr., twenty-one, were arrested and charged with murder. Id. Mullins pleaded guilty early on and testified against Butler who was convicted of capital murder and sentenced to life without parole. Accomplice Convicted in Killing, N.Y. TIMES, Aug. 6, 1999, at A15; Killer of Gay Man in Alabama Gets Life in Prison Without Parole, N.Y. TimES, Aug. 7, 1999, at A14.

157 Reeves, supra note 156. Mullins had planned to kill Gaither because of sexual advances that Gaither had made toward him. Kevin Sack, 2 Confess to Killing Man, Saying He Made A Sexual Advance, N.Y. TIMES, Mar. 5, 1999, at A10; Pressley, supra note 156, at A1; Alabamian Convicted, Gets Life in Murder of Gay Man, COM. APPEAL, Aug. 6, 1999, at A9. Mullins invited Butler to come along, and Mullins claimed that Butler understood from the beginning what was to happen that night. 


\section{VICTIM-OFFENDER MEDIATION: THE FUTURE RESPONSE TO HATE CRIMES}

Hate crimes have long been a tragic part of American history. ${ }^{158}$ The increase in incidents of hate crimes in recent years signifies that this nation still has a long way to go in its hate crimes prevention efforts. ${ }^{159}$ Crimes committed against individuals on the basis of skin color, religion, and sexual preference remain a powerful presence in today's society. The need to deal with hate crimes is essential in light of the increasing brutality of these biasmotivated crimes. ${ }^{160}$ There are two overarching paradigms that can be integrated in an effort to deal appropriately with hate crimes and to deter such incidents in the future: hate crimes legislation and the implementation of a victim-offender mediation model.

\section{A. The Development of Hate Crimes Legislation}

The first paradigm in place for combating hate crimes is the implementation of some form of hate crimes legislation. The failure to address incidents of hate crimes through legislation will in effect "leave[ ] entire groups of people feeling isolated and vulnerable."161 Therefore, in an effort to curtail incidents of hate, Congress and the states have been making great strides in developing new legislation. ${ }^{162}$ Numerous laws have been enacted that provide enhanced sentencing "for crimes motivated by officially

158 APA Position Paper, supra note 104.

159 See supra Part V.

160 See supra Part V.

161 APA Position Paper, supra note 104.

162 As of 1997, "[f]orty-seven jurisdictions across the United States have enacted some form of legislation designed to combat hate crimes. Thirty-nine States have enacted laws against bias-motivated violence and intimidation." NCJA, supra note 19, at xiii. In addition,

The Hate Crimes Prevention Act of 1998, introduced in both the House (H.R. 3081) and Senate (S. 1529), seeks to expand federal jurisdiction over hate crimes by (1) allowing federal authorities to investigate all possible hate crimes, not only those where the victim was engaged in a federally protected activity such as voting, going to school, or crossing state lines; and (2) expanding the categories that are currently covered by hate crimes legislation to include gender, sexual orientation, and disability.

APA Position Paper, supra note 104. 
disfavored prejudices,"163 and many states have developed substantive hate crimes laws. ${ }^{164}$

Undoubtedly, the development of hate crimes legislation is vital to combating the recurrence of hate crimes in this country. However, the underlying concern with hate crimes legislation is that it only serves political

163 Jacobs \& Potter, supra note 100 , at 1. Statutes that provide for enhanced sentencing "either upgrade an existing offense or increase the maximum penalty for offenses motivated by prejudice." Id. at 7 (citations omitted). There is no uniformity among the hate crimes legislation enacted in the various states. Id. at 6 . Hate crimes laws vary greatly from state to state. Id. These laws "differ, not only with respect to which prejudices transform 'ordinary' crime into hate crime, but according to which predicate crimes, when motivated by prejudice, qualify as hate crimes." Id.

$164 \mathrm{Id}$. at 5 . Although hate crime statutes have been established throughout the country, the enactment of these laws has been met with much resistance. Opponents of hate crimes laws challenge these statutes on the basis "that they violate the first amendment of the U.S. Constitution, which restricts governments' power to make laws infringing upon an individual's freedom of speech and expression." NCJA, supra note 19 , at 27. Opponents believe hate crimes laws to be "viewpoint discrimination" in that they penalize an individual offender for his or her thoughts by punishing that person more harshly when he or she "commits a crime because of bias against a class of persons." Id. Furthermore, opponents argue that because existing criminal law already punishes individuals who engage in injurious conduct, "recriminalization or sentence enhancement for the same offense when it is motivated by prejudice amounts to extra punishment for values, thoughts, and opinions which the government deems abhorrent." Jacobs \& Potter, supra note 100, at 10 (citing Steven M. Freeman, Hate Crime Laws: Punishment Which Fits the Crime, 93 ANN. SuRv. AM. L. 581 (1992/1993); Susan Gellman, Hate Crime Laws Are Thought Crime Laws, 93 ANN. SuRV. AM. L. 509 (1992/1993); David Goldberger, Hate Crime Laws and Their Impact on the First Amendment, 93 ANN. SURV. AM. L. 569 (1992)). Despite constitutionality arguments raised by opponents of hate crimes legislation, proponents of these laws maintain that "hate crime statutes do not conflict with the tenets of the first amendment because they do not punish an individual for exercising freedom of expression but rather for motivation for engaging in criminal activity, a factor often considered when evaluating the seriousness of an offense." NCJA, supra note 19, at 29. Proponents argue that bias-motivated crime warrants more severe penalties "because the injury suffered by the victim and by society is greater" when an offender has a biased motive. $I d$. The debate as to the constitutionality of hate crime statutes continues among constitutional scholars and civil libertarians, as the United States Supreme Court has yet to reach any definitive answer as to the constitutionality of these statues. See R.A.V. v. City of St. Paul, 505 U.S. 377 (1992) (striking down a biasmotivated crime ordinance as facially unconstitutional because it prohibited otherwise permitted speech solely on the basis of the subjects the speech addressed and while the statute served a compelling interest, there were content-neutral alternatives available); see also Wisconsin v. Mitchell, 508 U.S. 476 (1993) (holding defendant's First Amendment freedom of speech rights were not violated by application of the Wisconsin penaltyenhancement provision and that the statute was not constitutionally overbroad). 
and symbolic functions. ${ }^{165}$ Hate crimes legislation is emblematic in that it permits the public to perceive the legislature as taking a "tough on crime approach" because the legislature is making strong efforts to label these particular offenders and in most cases is providing harsher sentences for those who commit these offenses. ${ }^{166}$ In essence, the legislature is doing nothing more than applying the traditional values of the criminal justice system to new legislation-punishment without reparation. ${ }^{167}$

The enactment of legislation alone is not the answer to curtailing hate crimes because it fails to provide the sense of justice originally intended as a basis for establishing hate crimes legislation. Specifically, hate crimes legislation fails to address the needs of the victims. Recognizing these needs is imperative given that many victims of hate crimes are not reporting the incidents despite the increase in hate crimes legislation. ${ }^{168}$ There are a myriad of reasons why hate crimes go unreported, one in particular being victims' uncertainty whether perpetrators will be brought to justice. ${ }^{169}$

If hate crimes legislation was designed to help those individuals who fall prey to bias-motivated crime as a result of their race, religion, sexual orientation or other distinguishing feature, then it needs to reassure those individuals that they are being protected and that there is some discernible benefit from prosecuting offenders under a hate crimes statute. Hate crimes legislation is purely retributive in that it only punishes hate-crime offenders after they have committed a bias-motivated crime. In essence, similar to other criminal laws, hate crimes legislation provides little opportunity for offender accountability or personal empowerment for victims. Hate crimes legislation as it now exists is not meeting the needs of victims, offenders, or the community. If hate crimes are going to be dealt with effectively and there is going to be a lasting impact on the offender, it is essential that there be a

165 Jacobs \& Potter, supra note 100 , at 1.

166 See id. at 7.

167 See supra Part II.A.

168 NCJA, supra note 19 , at 10 . Despite the fact that many victims flat out refuse to report an incident of hate crime committed against them, there are those victims who have reported them, but either they were not "taken seriously or the incident was not pursued as a hate crime." Id.

${ }^{169}$ Id. at xii. Another reason for victims not reporting hate crimes is their desire "to avoid the humiliation of recounting the event." Id. There is also fear among victims "that the criminal justice system is biased against the group to which the victim belongs and, consequently, that law enforcement authorities will not be responsive." APA Position Paper, supra note 104. Sexual minorities in particular "are reluctant to report an incident because they might be forced 'out of the closet' and would suffer repercussions to their career and relationships with family and friends from such an 'outing."' NCJA, supra note 19 , at 10 . 
system put in place that provides not only for punishment of the offender, but for rehabilitation of the offender as well as reparation for the victim.

\section{B. The Implementation of a Victim-Offender Mediation Model}

Hate crimes legislation is only one means of dealing with recurring incidents of hate crime. This Note proposes that there exists a second paradigm for the prevention of hate crimes. By electing to utilize some form of restorative justice, the needs of hate crimes victims will be brought to the forefront, and the underlying goals for establishing hate crime legislation will be more appropriately met. ${ }^{170}$ Specifically, by implementing a victimoffender mediation process to compliment existing legislation, punishment and rehabilitation will be able to coexist, which in the end will provide a greater benefit to both victim and offender.

Victim-offender mediation is applicable to a wide range of crimes and has proven successful even in cases involving severely violent crimes. ${ }^{171}$ Hate crimes may vary in degree from property crimes such as vandalism to more severe crimes such as murder. ${ }^{172}$ In recent years, the crimes that have raised national attention have been of the most brutal caliber. ${ }^{173}$

Whether minor or severe, any hate crime causes far more damage to both victim and offender than other types of offenses. ${ }^{174}$ Hate crimes, unlike other types of crimes, are driven by characteristics inherent to the personality of the offender. ${ }^{175}$ They are not crimes of greed or lust, but rather of personal prejudice, denoting the underlying attitudes and values of individual offenders. ${ }^{176}$ Because the goal of the victim-offender mediation process is to delve beyond the crime itself and explore the underlying thoughts and feelings of both victims and offenders, it seems that this process would reveal the very premise that often leads offenders to commit hate crimes. Such a restorative process would therefore be specially beneficial in handling hate crimes. ${ }^{177}$

\footnotetext{
170 See supra Part II.B.

171 See supra Part III.C.

172 See supra Parts IV and V.

173 See supra Part V.A-C.

174 NCJA, supra note 19, at 29.

175 Jacobs \& Potter, supra note 100, at 2.

176 Id.
}

177 Researchers have determined "that hate crimes are not necessarily random, uncontrollable, or inevitable occurrences." APA Position Paper, supra note 104. Rather, there exists "overwhelming evidence that society can intervene to reduce or prevent many forms of violence, ... including the hate-induced violence that threatens and intimidates entire categories of people." Id. This research suggests that hate crimes could be 
There is immeasurable value in utilizing victim-offender mediation in incidents of hate crimes. In particular, there are three principal benefits to be derived by both victims and offenders who engage in the victim-offender mediation process. First, victim-offender mediation humanizes the criminal justice process. ${ }^{178}$ Providing for a human element is particularly important in instances of hate crimes because these crimes are premised on harm caused to a particular individual. If a hate crimes offender is punished pursuant to hate crimes legislation, there will likely never be the opportunity to understand how the offender affected a particular individual. However, if victim and offender are afforded the opportunity to meet, it will force the offender to learn of the extent of the damage as well as the reason why his or her actions were so offensive to a particular person or group of people. Moreover, victim-offender mediation provides a forum in which the victim can break down any stereotypes and prejudices held by the offender, which will in turn educate the offender as to the true perception of a certain group of people.This may deter the offender from committing crimes of a similar nature in the future. ${ }^{179}$

Second, victim-offender mediation provides an emotional release for both the victim and offender. ${ }^{180}$ This is an important benefit of victimoffender mediation because hate crimes are so highly sensitive and elicit an enormous array of emotions. In general, victims of hate crimes suffer serious psychological effects, more so than do victims of other crimes. ${ }^{181}$ Common characteristics among hate crimes survivors include depression, stress, and

appropriately dealt with in victim-offender mediation because the mediation process provides a means for both victims and offenders to express their feelings. Therefore, the opportunities to communicate with one another about whatever feelings prompted the offender to commit such a crime will likely aid in deterring him or her from committing such acts in the future.

178 Research has revealed that "[ $t]$ he victim-offender mediation process has a strong effect in humanizing the justice system's response to crime for both victims and juvenile offenders." UMBREIT, supra note 72, at 156.

179 For instance, according to Bruce Steele, editor of The Advocate, there are many people who still perceive gays and lesbians as threats. Reeves, supra note 156 . He believes that until these perceptions are "educated away" hate crimes will continue to happen. Id.

180 See Cottam, supra note 16 , at 1537.

181 Parents, Families and Friends of Lesbians and Gays (PFLAG), Hate Crimes Hurt Families, at http://www.pflag.org/publications/hatecrimes.pdf (last visited Oct. 12, 2001). This is particularly true for anti-gay hate crimes. Id. Since "anti-gay hate crimes are attacks on identity, they may have more serious psychological effects on victims than do other crimes." Id. 
anger. ${ }^{182}$ In addition, hate crimes usually invoke memories of past incidents by members of a particular targeted group. In the case of hate crimes committed against African Americans, whenever such incidents occur there is a tremendous "impact upon the entire society not only for the hurt they cause but for the history they recall, and perpetuate." 183 Similarly, crimes committed against Jews arouse comparable feelings of vulnerability and persecution. ${ }^{184}$

Engaging in victim-offender mediation will also present an excellent opportunity for the offender to release some emotion and relieve the individual from the stigma of being labeled an offender. ${ }^{185}$ For example, victim-offender mediation may have been useful in the case of Aaron McKinney, one of the men convicted for killing Matthew Shepard. ${ }^{186}$ In that case, McKinney pled to the court that he was sorry for what he had done and was truly ashamed. ${ }^{187}$ Participating in victim-offender mediation would have provided McKinney with an opportunity to release some of this emotion as well as express his sentiments to the parents of Matthew Shepard. ${ }^{188}$

Third, victim-offender mediation fills many of the gaps in hate crimes legislation. By placing emphasis on the victim's needs, victim-offender mediation will likely encourage victims to report future incidents of hate crimes because it helps victims to recognize that reporting is part of the healing process and that they have the power to overcome what has happened. ${ }^{189}$ In addition, unlike hate crimes legislation, victim-offender mediation assures a reduction in recidivism. 190 By engaging in victimoffender mediation, offenders are less likely to recidivate because once an offender has had an opportunity to meet the victim it becomes more difficult to rationalize committing such crime in the future. 191 For hate crimes offenders in particular, a face-to-face meeting with the victim will hopefully

182 Id. These types of feelings "are more prevalent in hate crime survivors than in survivors of comparable non-bias motivated crimes." Id. Specifically, feelings such as these "can last up to five years for gay and lesbian victims of hate crimes, while lasting up to two years for victims of non-bias-related crimes." Id.

183 Faces of Hate Crimes, supra note 130.

184 Id.

185 See supra Part III.B.

186 See supra Part V.C.

187 McKinney, supra note 153.

188 In the case of Matthew Shepard, victim-offender mediation may have been an important step for both the victim's parents and the offender after the offender was sentenced.

189 Incidents of Hate Crime, supra note 136.

190 See supra note 75 and accompanying text.

191 See supra Part III.B. 
make it harder for them to maintain the same biases they held before the mediation.

It is imperative that victim-offender mediation play an integral role in dealing with and preventing hate crimes. The benefits that it provides to both victim and offender are numerous. The overall implication of expanding the scope of victim-offender mediation to hate crimes is that it will instill a sense of justice that has ceased to exist in the American criminal justice system.

\section{CONCLUSION}

The restorative justice movement is slowly changing the face of the American criminal justice system, teaching us that "[t]he problem of crime can no longer be simplified to the problem of the criminal." 192 Crime is more than breaking the law; it "injures individual victims, communities, offenders, and their families, and it damages relationships."193 Restorative justice acknowledges that there is much more at stake than the fact that a crime has been committed. The restorative justice vision requires the criminal justice system to delve beyond the surface of crime and to examine closely the harm it causes to real people.

Victim-offender mediation has emerged as the most commonly used form of restorative justice. ${ }^{194}$ Although widely used, this country has only begun to "[push] the envelope" of victim-offender mediation. ${ }^{195}$ In the coming years, there will be continued efforts to expand the application of victim-offender mediation and improve upon the process to allow for maximum healing potential in all crimes that are mediated. ${ }^{196}$

Hate crimes are a paramount example of an area that necessitates a victim-offender mediation process. Hate crimes are much more than a criminal act because they represent deep-rooted biases and are extremely detrimental to both targeted victims and their greater communities. In recent years there have been widespread efforts to curtail hate crimes, as is evidenced by the increase in hate crimes legislation. However, apprehension as to the effectiveness of this legislation has created an overwhelming need to consider other alternatives.

In dealing with incidents of hate crimes, any measures to be taken by the criminal justice system cannot be purely punitive; a restorative approach is also needed. The only way to truly "stop the hate" so that it does not continue

192 Bazemore, supra note 36 , at 86.

193 Id.

194 Umbreit, supra note 13.

195 The State of the Art, supra note 32.

${ }^{196}$ Id. 


\section{VICTIM-OFFENDER MEDIATION}

to plague future generations of this country is to establish an effective method of prevention. As this Note proposes, the future of hate crimes prevention lies in a well-integrated system providing for both the application of hate crimes legislation as well as the utilization of a victim-offender mediation process. 
